RESIDENT

\& FELLOW

SECTION

Section Editor

Mitchell S.V. Elkind,

MD, MS

\title{
Video NeuroImage:
}

\section{Diagnosing conversion weakness with the}

Spinal Injuries Center test

\section{When Hoover doesn't help}

囷

W. Curt LaFrance, Jr., $\mathrm{MD}, \mathrm{MPH}$

Address correspondence and reprint requests to Dr. W. Curt LaFrance, Jr., Rhode Island Hospital, 593 Eddy Street, Potter 3, Providence, RI 02903 William_LaFrance_Jr@Brown.edu

The Hoover sign has been used since 1908 to aid in diagnosing conversion paralysis in unilateral lower extremity weakness. The abductor sign tests the same finding in the horizontal plane. ${ }^{1}$ Recently the Spinal Injuries Center (SIC) test has been shown to be a highly sensitive and specific sign for lower extremity weakness. ${ }^{2}$ Patients who are unable to raise their knees spontaneously are considered to have a positive SIC test (confirming conversion paralysis) when their knees maintain the lifted position after being placed by the examiner.
The videos demonstrate the SIC test in unilateral hemiplegia, paraplegia, and conversion weakness.

\section{REFERENCES}

1. Sonoo M. Abductor sign: a reliable new sign to detect unilateral non-organic paresis of the lower limb. J Neurol Neurosurg Psychiatry 2004;75:121-125.

2. Yugué I, Shiba K, Ueta T, Iwamoto Y. A new clinical evaluation for hysterical paralysis. Spine 2004;29:19101913. 


\title{
Neurology
}

\author{
Video NeuroImage: Diagnosing conversion weakness with the Spinal Injuries Center \\ test: When Hoover doesn't help \\ W. Curt LaFrance, Jr \\ Neurology 2008;71;e57 \\ DOI 10.1212/01.wnl.0000334400.86829.6d
}

\section{This information is current as of November 3, 2008}

\section{Updated Information \&} Services

Supplementary Material

\section{References}

Subspecialty Collections

Permissions \& Licensing

Reprints including high resolution figures, can be found at: http://n.neurology.org/content/71/19/e57.full

Supplementary material can be found at: http://n.neurology.org/content/suppl/2008/10/31/71.19.e57.DC1

This article cites 2 articles, 1 of which you can access for free at: http://n.neurology.org/content/71/19/e57.full\#ref-list-1

This article, along with others on similar topics, appears in the following collection(s):

All Movement Disorders

http://n.neurology.org/cgi/collection/all_movement_disorders

Clinical neurology examination

http://n.neurology.org/cgi/collection/clinical_neurology_examination

\section{Conversion}

http://n.neurology.org/cgi/collection/conversion

Dystonia

http://n.neurology.org/cgi/collection/dystonia

Spinal cord infarction

http://n.neurology.org/cgi/collection/spinal_cord_infarction

Information about reproducing this article in parts (figures,tables) or in its entirety can be found online at:

http://www.neurology.org/about/about_the_journal\#permissions

Information about ordering reprints can be found online:

http://n.neurology.org/subscribers/advertise

Neurology ${ }^{\circledR}$ is the official journal of the American Academy of Neurology. Published continuously since 1951, it is now a weekly with 48 issues per year. Copyright . All rights reserved. Print ISSN: 0028-3878. Online ISSN: 1526-632X.

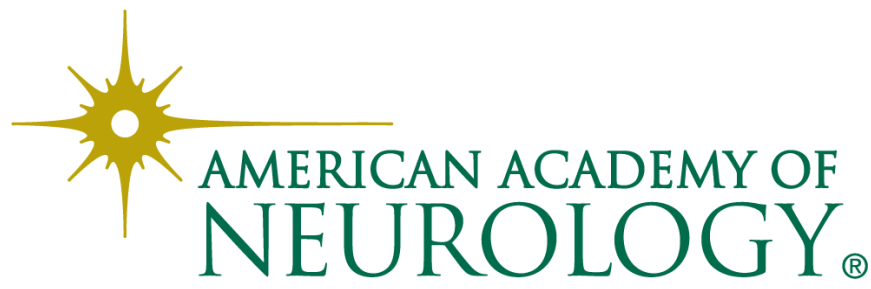

